Marquette University

e-Publications@Marquette

2-1-2006

Finding the Sweet Spot: A Two Industry Study Using the Zone of Tolerance to Identify Determinant Service Quality Attributes

Srinivas Durvasula

Marquette University, srinivas.durvasula@marquette.edu

Antonio Lobo

Swinburne University of Technology

Steven Lysonski

Marquette University, steven.lysonski@marquette.edu

Subhash Mehta

Kazakhstan Institute of Management

Post-print.

Journal of Financial Services Marketing, Volume 10, No. 3 (February 2006), DOI: 10.1057/

palgrave.fsm. 4770190. 


\section{Finding the Sweet Spot: A Two Industry Study Using the Zone of Tolerance to Identify Determinant Service Quality Attributes}

Authors: Srinivas Durvasula, Antonio C. Lobo, Steven Lysonski \& Subhash C. Mehta

Abstract: This paper makes a detailed comparison of two major financial services in Singapore: life insurance and stockbrokerage. Relationships of perceptions and expectations of service quality, mean service adequacy (MSA) and mean service superiority (MSS) with service satisfaction and loyalty are examined. Results indicate that the reliability aspect of service quality is strongly related to satisfaction and loyalty in the stockbrokerage industry, while the assurance aspect of service quality enjoyed a similar status in the life insurance industry. Results also confirm that while MSA and MSS both drive satisfaction and loyalty, perceptions of actual service have the strongest correlations with those behavioural outcomes. The findings of this paper present some interesting managerial implications.

\section{Introduction}

The theme of satisfying customers has taken on a monolithic status both in industry and in services research. Founded on the belief that satisfaction drives loyalty which then drives profits, a plethora of studies has focused on empirically validating the connections among service-related variables and behavioural outcomes. Behind this background is a suspicion, however, that satisfied customers are not always likely to be faithfully loyal. Indeed, Jones and Sasser ${ }^{1}$ provide compelling evidence that even satisfied customers can defect and go elsewhere despite the fact that they are satisfied. What can account for such an anomaly? Xerox has found that customers who rate a firm as strongly satisfied ( 5 on a Likert scale) vs 4 (satisfied) are much more likely to be loyal customers and not defect to a competitor. Jones and Sasser ${ }^{1}$ found that this occurrence was likely in service related firms such as automobile, hospital, airline and telephone services. Such findings provoke the question of how customers can be made more satisfied so that they are likely to remain loyal in the long term.

This study argues that firms must drill deeper into understanding the dynamics of the multidimensional expectations of services and how these relate to overall service quality, satisfaction and behavioural intentions. The paper aims to probe into whether providing the desired service level is likely to be the sweet spot that can capture customers and induce them to

1 Durvasula, Lobo, Lysonski \& Mehta 
be loyal so that they are less likely to defect. Ostensibly, providing only the adequate level of service as compared to the desired level of service is most likely to be less powerful in driving behavioural intentions. To explore this theme the paper examines the 'zone of tolerance', service adequacy, service desired and how satisfaction and behavioural intentions are related to these two service levels. These concepts allow penetration beneath the surface of satisfaction and identification of the dynamics that operate in producing satisfaction and loyalty.

Two industries (stockbrokerage and insurance) were chosen for the investigation; both of these industries have offerings that are unarguably high in intangibility and credence properties. The analysis is based on data collected from two separate samples of subjects in Singapore; one sample evaluated stockbroker services while the other evaluated the services of life insurance agents. As stockbrokers and insurance agents rely upon repeat business to sustain profitability, understanding these issues is of paramount importance. With rising recognition of the importance of customer retention and loyalty, companies that can understand such dynamics will be able to build upon marketing strategies specific to their needs. ${ }^{2}$ Further, the research contributes to the literature by advancing the zone of tolerance framework to two industries that have not been well investigated.

\section{The Stockbrokerage and Life Insurance Industries Stockbrokers}

Empirical research investigating the service aspects of the stockbrokerage industry is almost nonexistent. Based on what is known, however, the delivery of proper service is one strategy that has been related to success for stockbrokerage firms. ${ }^{3}$ With the advent of online trading and state-of-the-art technology interfaces, service quality is becoming a critical differentiator among brokers. ${ }^{4}$ Advertising themes now stress service quality indicators such as broker reliability, trustworthiness, and the eagerness that brokers show in the personal interest of each customer's situation. ${ }^{5}$

The services provided by stockbrokers encompass a number of unique characteristics that differentiate this sector from other financial services industries. In shares trading, both parties (the broker and the client) communicate about the price and number of lots to buy or sell for a particular stock. The perceived performance of the broker, to a great extent, is only evident once the service is provided in the form of share purchase and their appreciation or depreciation. Intangibility is very high as brokerage services are performances rather than objects. The heterogeneity in terms of quality of service rendered makes this type of service very

2 Durvasula, Lobo, Lysonski \& Mehta 
labour-intensive. As quality and essence of the service can vary widely from broker to broker, from customer to customer, and from day to day, it is difficult for stockbroking houses to achieve standardisation and quality control. Stockbroker's services are also perishable because they cannot be inventoried, resulting in a problem of coordinating demand and supply. In a bull market, many investors find it difficult to contact their brokers; whereas during a bear market brokers are easily available as most investors are reluctant to do many transactions. Given these dynamics, the way service quality drives satisfaction and loyalty may be different in the stockbrokerage industry as compared to other financial service industries.

\section{Life insurance}

Life insurance providers offer services that are credence products with very few cues to signal quality. It has been suggested that consumers usually rely on extrinsic cues like brand image to ascertain and perceive service quality. ${ }^{6}$ This factor is especially true for a 'pure' service such as insurance, which has minor tangible representations of its quality and is highly relational during most transactions. There is also a lack of price signal in the market due to specialised customer needs and difficulty in comparing prices; thus consumers cannot rely solely on price as an extrinsic cue to signal quality.

The outcomes of life insurance purchase are often delayed, and thus do not allow immediate post-purchase valuation. As such, the consequences of a purchase do not produce an immediate reaction towards overall satisfaction. This situation is more apparent as the future benefits of the 'product' purchased are difficult to foresee and it takes a long time to 'prove' its effects. ${ }^{7}$ Infrequent purchase and 'usage' of such credence products by consumers would mean an inability or difficulty in forming service expectations due to limited understanding of and familiarity with the service. ${ }^{8}$ At the same time, because of the amount of money that is typically invested in an insurance policy, customers seek long-term relationships with their insurance companies and respective agents in order to reduce risks and uncertainties. ${ }^{9}$ Pure services like insurance may, therefore, conjure different expectations from those of services that include tangible products. ${ }^{10}$

An insurance policy is almost always sold by an agent who, in 80 per cent of the cases, is the customer's only contact. ${ }^{11}$ Customers are, therefore, likely to place a high value on their agent's integrity and advice. ${ }^{12}$ The quality of the agent's service and their relationship with the customer serves either to mitigate or to aggravate the perceived risk in purchasing the life insurance product. Putting the customer first, and exhibiting trust and integrity have been found to be essential in selling insurance. ${ }^{13}$ Yet, Sherden ${ }^{14}$ laments that high quality service (defined as 
exceeding 'customers' expectations') is rare in the life insurance industry but increasingly demanded by customers.

Toran $^{12}$ points out that quality should be at the core of what the insurance industry does. Customer surveys by Prudential have identified that customers want more responsive agents with better contact, personalised communications from the insurer, accurate transactions and quickly solved problems. ${ }^{15}$ A different study by the National Association of Life Underwriters found other important factors such as financial stability of the company, reputation of the insurer, agent integrity and the quality of information and guidance from the agent. ${ }^{16}$ Clearly, understanding consumers' expectations of life insurance agents' service is crucial as expectations serve as standards or reference points against which service performance is assessed. ${ }^{17}$ Technology has also become an important factor in how the agent operates in the field ${ }^{18}$ including other functions such as distribution, claim costs and administration. ${ }^{19}$

In sum, both stockbrokerage and life insurance are pure services that represent two different sectors of the financial services industry. Although each has some similarities with the other, the differences are much more marked. In the case of stockbrokers, the results or benefits of the service provider are seen by the customer in the short term after a trade has been executed. In contrast, the results of life insurance are far removed in the distant future when the policy is redeemed upon the death of the benefactor. Even the terms used to describe the customers are different; in the stockbrokerage sector customers are called 'investors' while in the life insurance business customers are termed 'beneficiaries' or 'benefactors'. Consequently, there is likely to be a variation in the importance of certain service quality attributes between the two industries. The dominance of some attributes is more likely to drive service satisfaction and future intentions in stockbrokerage differently from life insurance. One goal of this study is to identify which service quality attributes are the most strongly related to customer satisfaction and loyalty in each of the industries. Table 1 captures some of the major differences between the two industries.

\section{Service Quality, Satisfaction and Behavioral Intentions}

\section{Service quality and its consequences}

Service quality has emerged as a key variable in understanding differences between service firms. Early proposals define service quality as a result of the gap between customers' expectations and their perceptions of the performance of the service. ${ }^{6,20}$ This conception of service quality has been popularly known as the 'Gap Model'. More recently, service quality has

4 Durvasula, Lobo, Lysonski \& Mehta 
also been defined broadly as 'consumers' assessment of the overall excellence or superiority of the service'. ${ }^{21}$ It is viewed as an attitude or global judgment about the overall excellence of a service, with comparison of expectations and performance as the measuring tools. . $2,23^{23}$

Service quality, therefore, is viewed as a critical component of customer perceptions of service. In the case of pure services, service quality will be the dominant element in customer's evaluations. The services literature posits that service quality is a critical predictor of perceptions of value ${ }^{23}$ and is an antecedent of satisfaction. ${ }^{24}$ Researchers have argued strongly that improved service quality leads to higher customer satisfaction. ${ }^{25}$ Customer satisfaction, then, is viewed as a critical driver of intentions to repeat purchase. Service quality is also seen as a driving force having an impact on behavioural outcomes such as positive word-of-mouth and repeat purchase intentions. ${ }^{26}$

\section{Behavioural intentions and their antecedents}

Behavioural intentions of customers resulting from the service delivery process are of crucial interest to companies in this era of relationship building in service management. Essentially, behavioural intentions are described by Zeithaml et al. ${ }^{27}$ as 'indicators that signal whether customers remain with or defect from the company'. In their research, behavioural intentions are classified as comprising both a favourable and an unfavourable element. The favourable element relates to positive word of mouth (WOM), recommending behaviour, loyalty to company, increased expenditure on the firm's services and a willingness to pay a price premium. The unfavourable element includes negative WOM, intentions to switch, complaining behaviour and decreased expenditure with the firm. Extant research shows that purchase intentions, loyalty, and recommending behaviour (ie positive WOM) are positively correlated with service quality and satisfaction. This finding is reflected in research by Cronin et al. ${ }^{28}$ and Durvasula et al. ${ }^{29}$ while context-specific studies done, for example in hospitals, the hospitality industry and schools also arrive at the same conclusion. ${ }^{30-32}$

\section{Multi-expectations framework: Zone of tolerance}

In their original framework for measuring service quality, Parasuraman et al. ${ }^{20}$ used a single expectation standard, desired expectations (ie what a consumer feels a service provider should offer) as a comparison against which service performance is assessed. More recently, these same authors have developed an integrative model that captures both service quality and satisfaction perspective of expectations. Specifically, the model proposes that service expectations exist at two different levels: one is the desired level of service and the other is the adequate level of service. ${ }^{10}$ Between these two levels of expectations lies the zone of tolerance 
(ZOT), which represents a range of performance that the service consumer considers as acceptable. It has been suggested that the ZOT gap is affected by factors that determine both desired and adequate service expectations.

The ZOT framework offers a powerful way of understanding levels of satisfaction that may not be captured by the conventional way of measuring satisfaction. The ZOT difference scores were found to be less subject to response error compared to a single expectation measure of satisfaction. Moreover, such difference scores also provide more detailed information useful for diagnosing consumers' reactions to a service. Compared with the SERVQUAL instrument, the ZOT model offers a richer measure of service quality. It illustrates the difference between perceived service and desired service - known as Measure of Service Superiority (or MSS) and also the difference between perceived service and adequate service labelled as Measure of Service Adequacy (or MSA). In addition to improving the comprehension of the multiple expectations, understanding the concept of ZOT provides practitioners with better opportunities to enhance resource allocations in their continual attempt to meet or exceed customer expectations. ${ }^{17}$

Only a few studies have examined variations across service industries in the width of ZOT. In a study conducted by Chen, ${ }^{33}$ significant difference was found between the consumers' desired and adequate levels of in-flight service delivery of Philippine Airlines. It was also noted that customers who were below the adequate level were more ready to take their business elsewhere the moment they perceived a viable service alternative. By understanding customer's tolerance zone, the author could identify areas in the airline service that required improvements. Another study offered empirical support for the ZOT concept of expectations and provided a list of factors that might influence the width of consumers' zones of tolerance. ${ }^{17}$

Despite advances in measuring service quality, there still remains an incomplete understanding of how the level of service quality is likely to drive loyalty or other behavioural outcomes. Hence, researchers concluded that more empirical research was needed to verify and validate the relationship of each expectation component with its respective determinants. ${ }^{10}$

In sum, it is known that service quality is a determinant of satisfaction and behavioural intentions. Satisfaction is crucial to loyalty according to extant research as dissatisfied customers may defect to a competitor if they are not satisfied at the proper level. Satisfaction becomes the linchpin in the connection between quality and loyalty. The goal of this study is to explore the links in this process by using the multi-expectation paradigm which provides a powerful lens with which to look beneath the surface. The study will compare how overall perceptions, adequate 6 Durvasula, Lobo, Lysonski \& Mehta 
service, desired service, MSA, and MSS affect satisfaction and behavioural intensions. In particular, the aim is to assess how ZOT operates in this dynamic process. Two different industries which are pure services are examined as a way of seeing if these relationships may be common across service sectors. Although life insurance and stockbrokerage share commonalities (as noted above), the major differences between the two would suggest that different relationships would emerge. The research questions delineated in the next section reflect the nature of the inquiry in light of the insights garnered from the literature.

\section{Research Questions}

Data were gathered to give answers to the following research questions:

- What are the differences between perceptions, adequate service expectations and desired service expectations for the five service quality dimensions? Are there variations in these differences between stockbrokerage and life insurance?

- What are the MSA and MSS for the five service quality dimensions and do these differ between the two industries? What are the zones of tolerance?

- What are the correlations of the five service quality dimensions for perceptions, adequate service, and desired service, MSA, MSS with the behavioural outcomes of satisfaction, attitudinal loyalty and behavioural loyalty? Which correlations are higher?

\section{Method}

\section{About the survey measures}

In both the life insurance and stockbrokerage studies, the questionnaire included a modified version of the SERVQUAL scale and measures of satisfaction, attitudinal loyalty and behavioural loyalty as discussed below.

\section{Service quality measure}

In the life insurance study a modified SERVQUAL scale was used that is relevant to the insurance industry. It was constructed by including items from the original five dimensions (Tangibles, Reliability, Responsiveness, Empathy and Assurance) of the SERVQUAL instrument. The items were refined and paraphrased in both wording and contextual application as appropriate to suit the life insurance sector. As part of this process, a focus group of ten respondents with previous insurance buying experience was conducted to find out which aspects of service quality they desired most in buying life insurance. Their responses formed 
the basis for preparing the final service quality scale consisting of 22 items.

In the stockbrokerage study a modified version of the SERVQUAL scale was also used. Published literature was helpful in generating a pool of scale. ${ }^{34,35}$ These items were subsequently revised and reworded on the basis of input from a group of local brokers in Singapore. The final version of this scale also had 22 items.

In both the life insurance and stockbrokerage studies, the 22-item service quality scale was applied to measure service perceptions as well as service expectations. The 22 -item desired and adequate service scales were side by side in one section while the 22-item perception scale was placed in a separate section. The anchors for the scale ranged from (1) low to (7) high.

\section{Satisfaction and behavioural intentions}

In both studies, the survey included measures of satisfaction and behavioural intentions. Satisfaction was measured with a three-item scale for both industries which paralleled questions used by others. ${ }^{7,23,27}$ In both samples, the three-item satisfaction scale was found to have acceptable reliability (coefficient alpha $>0.70$ ).

The behavioural intentions scale measured both attitudinal loyalty and behavioural loyalty. In the life insurance study, a two-item scale measured attitudinal loyalty (eg say positive things about the agent, recommend to others). A single-item scale was used in this study to measure behavioural loyalty (eg provide future business to the agent). The stock broker study included a single-item measure of attitudinal loyalty (eg recommend to others) and a two-item measure of behavioural loyalty (eg continue to give business to the broker, will move to a new brokerage if my broker moves there). For all of these measures, subjects provided their level of agreement on a seven-point scale ranging from low to high. The mean scores of satisfaction, attitudinal loyalty and behavioural loyalty ranged from 4.56 to 4.72 in the stockbrokerage sample and 4.57 to 5.06 in the life insurance sample.

\section{About the sample}

Purposive sampling method was used to select survey respondents in the life insurance study. Respondents had purchased either a whole life insurance policy and/or an endowment policy within a one-year period from an agent. This time requirement allowed recollections of their purchase experience and post-purchase reactions. Of the 210 survey forms distributed in Singapore, 189 forms were returned, representing a 90 percent response rate. Seven surveys were incomplete, thus giving a final sample of 182 .

In the stockbrokerage study, the relevant population was defined as investors who had 8 Durvasula, Lobo, Lysonski \& Mehta 
invested or transacted in the stock market for the past one year. This criterion was similar to that used by others. ${ }^{36,37}$ The survey was distributed to respondents who fulfilled this criterion at Raffles Place in Singapore. Raffles Place was chosen as it is the hub of Singapore's financial institutions especially stockbrokerage houses. A total of 240 questionnaires was given out in a period of four weeks. All respondents were requested either to mail back the completed questionnaire to the researcher or call the researcher for collection of the questionnaire once completed. A total of 170 questionnaires was returned out of the 240 distributed, giving a response rate of 71 percent. Twenty-three were later omitted due to incomplete data resulting in a final sample size of 147 .

For both data sets, the samples are fairly evenly divided by gender, with males comprising 46 percent of the sample in the life insurance study and 48 percent of the sample in the stockbroker study. The stockbrokerage sample had a higher percentage of people (63 per cent) whose monthly income was above $\$ 2500$ vs 45 percent in the life insurance sample.

\section{Results}

\section{Dimensionality and reliability of service quality measures}

Dimensionality tests show that there is some support for viewing service quality as a multidimensional construct. Results of these tests are presented in Table 2. As compared to the null model of no relationships between service quality scale items, the chi-square statistics are significantly lower (as is wished) when service quality is modelled as having five distinct, yet correlated dimensions. High values for goodness-of-fit index (GFI) and comparative fit index (CFI), coupled with a low root mean square error (RMR) indicate a strong fit with the hypothesised model - which in this case is that service quality has five distinct but correlated dimensions. The relative size of these indices points to a moderate model fit. Results are virtually consistent across the data, whether service perceptions and service expectations (adequate and desired) alone are considered or when looking at MSA and MSS which represent difference scores between perceptions and expectations. Between the two industries, however, fit statistics are somewhat stronger for the life insurance data.

While confirmatory factor analysis results provide only moderate support for the multidimensional service quality concept, across all service quality measures, individual service quality dimensions demonstrated acceptable reliability values (ie scale reliabilities are $>0.70$ ). ${ }^{38}$ The authors treated the five scale dimensions as separate dimensions as this is likely to give a better insight into what features of service quality drive satisfaction and behavioural intentions.

9 Durvasula, Lobo, Lysonski \& Mehta 
Therefore, the rest of the analyses are undertaken with the assumption that the five service quality dimensions are indeed distinct. Results presented in subsequent tables help to address the various research questions as described below. For the reader's ease, each research question is repeated with the results that were found in the analysis.

(1) Are there differences in mean values between perceptions, adequate level vs desired level for the five different SERVQUAL dimensions? Are there variations in these differences between stockbrokers and life insurance?

Table 3 provides the results while Figure 1 displays the relative location of mean service perceptions as compared with adequate and desired service expectations. Stockbrokers are rated most favourably on the assurance aspect, while the life insurance agents are rated most favourably on both the reliability and assurance aspects of service quality. In both industries, service provider perceptions are generally above the neutral point of 4 . The tangibles dimension in the stockbrokerage industry is an exception, where the mean is closer to the scale neutral point.

Mean scores of service provider perceptions, adequate service expectations, and desired service expectations are higher in life insurance compared with stockbrokerage. The last row of Table 3 shows the overall service quality index (SQ Index) which is obtained by averaging responses over the 22 scale items. This index is also significantly higher $(p<0.05)$ in the life insurance sample than in the stockbrokerage sample. Hence, life insurance respondents have a better perception of the five service quality attributes (or dimensions) than those dealing with stockbrokers. Yet, they also have higher expectations regarding adequate and desired service.

(2) What are the MSA and MSS for the five different SERVQUAL dimensions and do these differ between the two industries? What are the zones of tolerance?

Table 3 provides results concerning these gap scores. While MSA shows the gap between service perceptions and adequate service expectation, MSS describes the gap between service perceptions and desired service expectations. In the areas of tangibles, reliability and responsiveness stockbrokers' service is less than adequate. Life insurance agents' service is less than adequate on the assurance dimension. Overall, there is not much of a difference when comparing the MSA service quality index in the two industries.

10 Durvasula, Lobo, Lysonski \& Mehta 
In both industries, actual service is inferior to the desired service. There is a performance gap as indicated by MSS mean scores. While this gap is slightly wider in the stockbrokerage industry as compared with the life insurance industry, the overall MSS service quality index indicates that this difference is statistically insignificant $(p>0.05)$.

The ZOT, which is the difference between desired and adequate service expectations, is slightly wider in the life insurance industry vs the stockbrokerage industry. However, the mean ZOT index for the two industries (1.09 vs 1.11$)$ is about the same in a statistical sense $(p>0.05)$. Further, a comparison of MSA, MSS and ZOT mean scores show that the actual service rendered in both industries is fairly close to the respective adequate service expectations. This result implies that there is significant room for improving the service quality in both life insurance and stockbrokerage industries.

(3) What are the correlations of the five service quality dimensions for perceptions, adequate service, and desired service, MSA, MSS with the behavioural outcomes of satisfaction, attitudinal loyalty and behavioural loyalty? Which correlations are higher?

As shown in Table 4, correlations of service quality dimensions with related measures (eg satisfaction, attitudinal loyalty, and behavioural loyalty) are higher for 'perception' measures than for 'adequate service' expectations or 'desired service' expectations. On examination of the last column of Table 4, no significant difference is found between life insurance and stockbrokerage concerning the correlations of perceptions-based service quality index with related measures. When it comes to service expectations (adequate or desired), however, the correlation of service quality with related measures is stronger in the stockbrokerage industry. This result is because all correlation estimates for expectations are higher in size for the stockbrokerage sample. In 16 out of 36 correlation comparisons, the differences in correlations are also significant $(p<0.1)$. Such a finding implies that service expectations are more likely to drive satisfaction and behavioural intentions in the stockbrokerage industry than in the life insurance industry.

Table 5 provides correlations of MSA and MSS measures with related measures. When examining these correlations, it is obvious that they are relatively stronger in the life insurance sample compared with the stockbrokerage one. In fact, as shown in the last column of Table 5, the service quality indices, constructed from MSA and MSS scores have significantly higher correlations with satisfaction, attitudinal loyalty and behavioural loyalty in the life insurance

11 Durvasula, Lobo, Lysonski \& Mehta 
sample than in the stockbroker sample.

An interesting question is to ask whether the MSA measure of service quality or MSS-based service quality measure has a stronger correlation with behavioural outcomes? This question can be answered by comparing the correlations in the last two columns of Table 5 . While MSS correlations are slightly larger than MSA correlations in magnitude, they are not significantly different in a statistical sense $(p>0.05)$.

\section{Discussion and Implications}

The results of this study are particularly noteworthy in light of the changing business models in both industries. In the age of e-business, it is now much easier for customers to shop around and therefore be less loyal. Competing through quality service is likely to intensify in both industries. Nonetheless, it is important to note that stockbrokerage and life insurance are two different industries offering very different products. Customers have different expectations in each of these industries due to the nature of the offering, as observed in the findings. Customers of stockbrokers have lower expectations due in part to the risk and variability they know exist with investments. In contrast, those who buy life insurance do not perceive such risk or variability as a life insurance policy is more ostensibly clear-cut. Since both services are in the financial sector, they deal with money invested strictly for a long-term goal such as life insurance or for a mix of short-term and long-term goals such as are found with investments in financial instruments.

For stockbrokers, one service area that needs definite improvement is 'tangibles'. Tangibles deal with the office setting of the brokerage firm and even the professional appearance of those who work in the office. Most importantly, the existence of technology may play a big role in how customers perceive the tangible aspect of brokerage firms. If the brokerage firm can provide up-to-date quotes either on the telephone or the internet and can offer research advice from respected sources, customers are likely to rate the tangibility of the firm higher. The financial statements given to customers are also important. It is crucial that brokerage firms try to boost consumer perceptions on tangibles given the findings in this study.

For the stockbrokerage industry (among the SERVQUAL dimensions), responsiveness and assurance consistently have the strongest relationship with satisfaction and the two types of loyalty, while empathy enhances satisfaction. These results indicate that the bedside manner of stockbrokers is essential in the perception of quality and in gaining satisfaction and loyalty. Brokers need to be attuned to the needs of each customer in a personalised and empathetic fashion. Being available or responsive to customers is necessary if they call for assurance when 12 Durvasula, Lobo, Lysonski \& Mehta 
making a correct investment decision or in understanding the fluctuations in their portfolios. An empathetic broker is more likely to be perceived as responsive and concerned about the interests of the customer.

In the life insurance industry, in contrast, assurance has the strongest relationship with overall perceptions of satisfaction and loyalty. This finding makes sense because insurance represents a huge investment and customers evaluate highly those agents who are perceived to be trustworthy and make customers feel assured that they made the correct decision. In the personalised selling process of whole life insurance, Loo $^{39}$ cited the views of industry observers and experts that insurance products are a very personal matter where people enjoy the comfort of talking to experts who are knowledgeable on insurance. Moreover, the nature of the products was described as varied, making it difficult to judge the appropriateness of the products and creating a preference to talk to someone when a claim arises. These ideas confirm the critical role of the agent-policyholder relationship and the role of assurance in that relationship.

Reliability was also found to be an important dimension in the life insurance industry. Next to assurance, reliability is the factor with the strongest relationship with satisfaction and loyalty. Reliability implies that the agent will be prepared to deliver on the terms of the life insurance policy when it is redeemed. Reliability also means that the customer can count on the agent to resolve any problems should they arise.

In financial services, service quality can be better represented by perception measures as compared to gap scores such as MSS and MSA. This discovery is seen when inspecting correlations of various service quality measures with satisfaction and behavioural outcomes. The ZOT is about the same in both industries and its relatively large size indicates that both stockbrokers and life insurance agents have substantial room for improvement in how they serve their customers. In the stockbrokerage sector, the perceptions of service on tangibles, reliability and assurance factors are slightly below the minimum desired service level. These results may signal a red flag in that stockbrokers may be deficient in delivering the kind of service that customers want. Failure to deliver the appropriate service may produce defections to other brokerage firms and poor word of mouth. In the life insurance industry, perception of service on the assurance dimension is below that of the minimum desired level. This finding is clearly disturbing since the assurance dimension has the strongest correlation with satisfaction and loyalty. Clearly, if some customers feel that insurance agents are not knowledgeable or courteous and cannot convey trust and confidence, such customers will defect.

\section{Managerial implications}

13 Durvasula, Lobo, Lysonski \& Mehta 
The findings on the two industries examined provide several managerial implications. For example, the study substantiated the growing evidence that expectations drive evaluations of service quality by consumers. This finding implies service providers can no longer afford to ignore consumer expectations or possess a one-sided view of expectations. Rather, industry-specific assessment of expectations is vital to determine the precise levels of both adequate and desired expectations for various service quality dimensions. With such an understanding, more precise resource allocations could be made, as advocated by Walker and Baker ${ }^{17}$ to improve crucial aspects of service quality that are deemed important by consumers.

In life insurance as well as stockbrokerage, both MSA and MSS were found to be consistent predictors of satisfaction and behavioural intentions. Moreover, for different service quality dimensions, consumers attached differing levels of expectations. While for some dimensions meeting and/or exceeding the minimum level of expectations drove satisfaction and positive behavioural intentions, for other dimensions consumers expected their desired level of expectations to be met. The finding that MSS correlations with satisfaction and loyalty are larger (though not often in a statistically significant sense) than MSA correlations with those same measures implies that service providers need to examine how their service compares with desired service. Any significant performance gap with respect to desired service will hinder satisfaction and customer loyalty.

From a managerial perspective, understanding the ZOT framework has far-reaching implications for the effective delivery of service. Given that companies have limited resources, they are incapable of fulfilling or exceeding all the expectations investors have of their service providers. This study offers some insights into what aspects of service quality need improvement for the delivery of effective customer service and the management of customer expectations in view of these resource constraints.

Walker and Baker ${ }^{17}$ noted that customers have differing adequate expectations and narrower zones of tolerance when service attributes were perceived as more essential to the service context. For example, in the life insurance sample of this study, high service expectations and the narrowest ZOT for the assurance dimension of service quality was found. Yet, this also is the dimension which has the largest correlation with satisfaction and loyalty. In such a situation, the onus on the service provider is to meet customers' minimum or adequate expectations first on these attributes before moving on to the desired expectation standards.

As customers in both life insurance and stockbrokerage sectors are more likely to be satisfied and engage in positive behaviours if perceptions exceeded the adequate expectations

14 Durvasula, Lobo, Lysonski \& Mehta 
of service, it is necessary to maintain customers' perceptions within the ZOT. In doing so, service providers must realise that promises made to customers should be taken very seriously. Once promises are made, customers' adequate expectations would be adjusted upwards, making it even more difficult for service providers to meet or exceed these. As competition in the industry becomes more intense, however, it would be worthwhile to both life insurance agents and stockbrokers to provide 'surprises' to customers along the way to delight them, thereby surpassing the desired expectations of customers and enhancing chances of customer loyalty. The ultimate goal is to discourage defections and build this loyalty.

\section{Future research}

The concept of a multi-expectation framework on service quality is still in its infancy. Future research should identify the various antecedents of desired and adequate service levels. For instance, situational factors, advertising, price and word of mouth are several factors that might affect desired and adequate service level. Subsequent empirical research should look at the impact of these factors on customer expectations.

Another area for future investigation is to examine whether or not service quality expectations of inexperienced consumers differ from those of experienced customers and how these differences affect satisfaction and loyalty. In addition, there is no clear understanding of the impact of customer demographics on service expectations. Demographics may play an important role in service quality perceptions, affect service quality expectations, and influence the ZOT for different service quality dimensions. Looking into this area would offer insights to managers in formulating market segmentation strategies.

Future studies in this area should also measure changes in service quality expectations over time in order to have a better understanding of how MSS and MSA relate to satisfaction and loyalty. This is because service expectations are known to be affected by customers' immediate reaction to specific service encounters. ${ }^{40}$ Cross-sectional studies that measure service expectations at one point in time may understate or overstate true service expectations, depending on whether customers had a positive or negative experience with the service provider.

\section{Notes}

- Srinivas Durvasula is Professor and Edward A. Brennan Chair in Marketing at Marquette University in Wisconsin, USA. His research interests include modelling, service quality measurement, cross-national studies on consumer behaviour and advertising perceptions. He has written over 60 papers in various journals and conference proceedings.

15 Durvasula, Lobo, Lysonski \& Mehta 
- Antonio C. Lobo is Lecturer in Marketing, Faculty of Business \& Enterprise, Swinburne University of Technology, Melbourne, Australia. His research interests and journal publications are in the areas of services marketing, service quality and tourism marketing. $\mathrm{He}$ is presently involved in related consultancy work with organisations such as Caterpillar Inc.

- Steven Lysonski is Professor and Miles Research Scholar at Marquette University in Wisconsin, USA. His research includes service quality and satisfaction measurement, cross-cultural marketing, product management and measuring consumer decision-making styles. He has written over 70 papers in various journals and conference proceedings.

- Subhash C. Mehta is Professor of Marketing at Kazakhstan Institute of Management and Editor of Asian Journal of Marketing. He has wide international experience, having taught at universities in Australia, India, Mauritius, Singapore, UK, USA and now Kazakhstan. He has written over 50 papers in various journals, particularly in the area of services marketing.

\section{References}

1 Jones, T. and Sasser, W. E. (1995) 'Why satisfied customers defect', Harvard Business

Review, November-December, pp. 88-98.

2 Rudie, M. J. and Wansley B. (1985) 'The Merrill Lynch quality program', In Bloch, T., Upah, G. and Zeithaml, V. A. (eds) 'Services Marketing in a Changing Environment', American Marketing Association, Chicago, IL.

3 Rust, R.T. and Zahorik, A. J. (1993) 'Customer satisfaction, customer retention and market share', Journal of Retailing, Vol. 69, No. 2, pp. 193-215.

4 Anonymous (1991) 'Brokers taking new approach in 90s advertising', Marketing News, Vol. 25, No. 2, p. 9.

5 Kim, E. (1999) 'Hurts so good: The broker-dealer industry is going through a difficult evolution', Financial Planning, July 1, pp. 1-3.

6 Gronroos, C. (1984) 'A service-oriented approach to marketing of services', European Journal of Marketing, Vol. 12, No. 8, pp. 588-601.

7 Crosby, L. A. and Stephens, N. (1987) 'Effects of relationship marketing on satisfaction, retention, and prices in the life insurance industry', Journal of Marketing Research, Vol. 24, November, pp. 404-411.

8 Johnston, E. O., O'Connor, R. J. and Zultowski, W. H. (1984) 'The personal selling process in the life insurance industry', in Jacoby, J. and Craig, C. S. (ed.) 'Personal Selling: Theory, Research and Practice', Lexington Books, Lexington, MA.

16 Durvasula, Lobo, Lysonski \& Mehta 
9 Berry, L.L. (1995) 'Relationship marketing of services - growing interest, emerging perspectives', Journal of the Academy of Marketing Science, Vol. 23, Fall, pp. 236-245.

10 Zeithaml, V. A., Berry, L. L. and Parasuraman, A. (1993) 'The nature and determinants of customer expectations of service,' Journal of the Academy of Marketing Science, Vol. 21, No. 1, pp. 1-12.

11 Crosby, L. A., Evans, K. R. and Cowles, D. (1990) 'Relationship quality in services selling: An interpersonal influence perspective', Journal of Marketing, Vol. 54, July, pp. 68-81.

12 Toran, D. (1993) 'Quality service (quality everything!)', LIMRA'S MarketFacts, Vol. 12, No. 2, pp. 10-11.

13 Slattery, T. (1989) 'Special report: Nichols: we've forgotten the consumer', National Underwriter, Vol. 48, November, p. 11.

14 Sherden, W. (1987) 'The erosion of service quality', Best’s Review, Vol. 88, No. 5, p. 22.

15 Pointek, S. (1992) 'Outside interests: Making the move from lip service to real service', National Underwriter, Vol. 96, No. 44, p. 34.

16 King, C. (1992) 'Agents/policy owners split on service', National Underwriter, Vol. 41, October, p. 7.

17 Walker, J. and Baker, J. (2000) 'An exploratory study of a multi-expectation framework for services,' Journal of Services Marketing, Vol. 14, No. 5, pp. 411-431.

18 Ingrassia, P. V. (1994) 'Harnessing technology to remain competitive,' Best's Review (Property/casualty insurance edition), Vol. 95, No. 1, May, pp. 84-85.

19 Anonymous (2004) 'Seizing the initiative', Life Insurance International, April, pp. 11-12. 20 Parasuraman, A., Zeithaml, V. A. and Berry, L. L. (1985) 'A conceptual model of service quality and its implications for future research', Journal of Marketing, Vol. 49, Fall, pp. 41-50. 21 Parasuraman, A., Zeithaml, V. A. and Berry, L. L. (1988) 'SERVQUAL: A Multiple-item scale for measuring consumer perceptions of service quality,' Journal of Retailing, Vol. 64, No. 1, pp. 12-40.

22 Bitner, M. J. (1990) 'Evaluating service encounters: The effects of surroundings and employee responses,' Journal of Marketing, Vol. 54, April, pp. 69-82.

23 Bolton, R. N. and Drew, J. H. (1991) 'A multistage model of customers' assessments of service quality and value', Journal of Consumer Research, Vol. 17, No. 4, pp. 375-384.

24 Brady, M. K., Cronin, J. J., and Brand, R. R. (2002) 'Performance-only measurement of service quality: A replication and extension,' Journal of Business Research, Vol. 55, January, pp. 17-31.

17 Durvasula, Lobo, Lysonski \& Mehta 
25 Anderson, E. W., Fornell, C. and Lehman, D. R. (1994) 'Customer satisfaction, market Share and profitability: Findings from Sweden,' Journal of Marketing, Vol. 58, No. 3, pp. 53-66.

26 Taylor, S. A. and Baker, T. L. (1994) 'An assessment of the relationship between service quality and customer satisfaction in the formation of consumers' purchase intentions,' Journal of Retailing, Vol. 70, No. 2, pp. 162-178.

27 Zeithaml, V. A., Berry, L. L. and Parasuraman, A. (1996) 'The behavioural consequences of service quality', Journal of Marketing, Vol. 60, April, pp. 31-46.

28 Cronin, J. J, Brady, M. K. and Hult, G. T. (2000) 'Assessing the effects of quality, value, and customer satisfaction on consumer behavioural intentions in service environments,' Journal of Retailing, Vol. 76, No. 2, pp. 193-218.

29 Durvasula, S., Lysonski, S., Mehta, S. and Tang, B. (2004) 'Forging relationships with services: The antecedents that have an impact on behaviourial outcomes in the life insurance industry', Journal of Financial Services Marketing, Vol. 8, No. 4, pp. 314-44.

30 Woodside, A., Frey, L. and Daly, R. (1989) 'Linking service quality, customer satisfaction and behavioural intentions', Journal of Health Care Marketing, Vol. 9, December, pp. 5-17.

31 Oh, H. (1999) 'Service quality, customer satisfaction and customer value: A holistic perspective', Hospitality Management, Vol.18, pp. 67-82.

32 Boulding, W., Kalra, A., Staelin, R. and Zeithamal, V.A. (1993) 'A dynamic process model of service quality: From expectations to behavioural intentions', Journal of Marketing Research, Vol. 30, February, pp. 7-27.

33 Chen, K. J. (1997) 'Consumer tolerance zone: implications on Philippine Airlines domestic service delivery', Journal of Global Marketing, Vol. 11, No. 2, pp. 93-105.

34 Furrer, O., Liu, B. S. C and Sudharshan, D. (2000) 'The relationship between culture and service quality perceptions - basis for cross-cultural market segmentation and resource allocation', Journal of Services Research, Vol. 2, No. 4, pp. 355-371.

$35 \mathrm{Lin}, \mathrm{X}$. and Wei, B. (1999) 'Service quality dimensions of securities brokerage firms: what customers consider as important', Journal of Professional Services Marketing, Vol. 20, No. 1, pp. $135-145$.

36 Chan, R., Chan, Y. K. and Yau, O. H. M. (1990) 'Selecting a broker or brokerage firm: segmentation of investors in the Hong Kong stock market,' Asia Pacific International Journal of Marketing, Vol. 3, No. 1, pp. 17-28.

18 Durvasula, Lobo, Lysonski \& Mehta 
37 Yau, O. H. M., Ip, Y. K. and Chan, D. Y. K. (1995) 'Selecting a broker or brokerage firm: segmenting investors in the Australian stock market', Journal of Professional Services Marketing, Vol. 12, No. 1, pp. 19-38.

38 Nunnally, J. C. (1978) 'Psychometric theory', 2nd edn, McGraw-Hill, New York, NY.

39 Loo, F. (2000) 'Buying insurance on the net', Financial Planner, February, pp. 58-60.

40 Clow, K. F. and Vorhies, D. W. (1993) 'Building a competitive advantage for service firms', Journal of Services Marketing, Vol. 7, No. 1, pp. 22-32.

\section{Appendix}

\section{Table 1}

\section{Major differences between insurance and stockbrokerage services}

\begin{tabular}{lll}
\hline Perceived characteristic & Insurance services & Stockbrokerage services \\
\hline 1 Customer turnover & Low & High \\
2 Feedback & Low & High \\
3 Word-of-mouth & Low & High \\
4 Information access & Low & High \\
5 Frequency of contact & Low & High \\
6 Tangibility of outcome & Low & High \\
7 Risk & Low & High \\
8 Rewards to provider & Low & High \\
9 Time pressure & Low & High \\
10 Need & High & Low \\
11 Loyalty to organisations & High & Low \\
12 Planning horizon & Long & Short \\
13 Commitment & Very long-term & Short/medium term \\
\hline
\end{tabular}

\section{Table 2}

\section{Scale fit statistics}

Scale fit statistics

\begin{tabular}{|c|c|c|c|c|c|c|c|c|c|c|}
\hline \multirow{2}{*}{$\begin{array}{l}\text { Service } \\
\text { quality factor }\end{array}$} & \multicolumn{2}{|c|}{ Perceptions } & \multicolumn{2}{|c|}{ Adequate Service } & \multicolumn{2}{|c|}{ Desired Service } & \multicolumn{2}{|l|}{$M S A$} & \multicolumn{2}{|l|}{ MSS } \\
\hline & Stkbrkr & Life ins & Stkbrkr & Life ins & Stkbrkr & Life ins & Stkbrkr & Life ins & Stkbrkr & Life ins \\
\hline$\chi^{2}(199 \mathrm{df})$ & 707.05 & 481.37 & 655.54 & 482.99 & 656.76 & 525.16 & 540.44 & 438.56 & 454.10 & 489.69 \\
\hline$\chi^{2}$ null (231 df) & 2560.66 & 2532.65 & 2851.85 & 2513.89 & 2855.19 & 3286.16 & 1912.73 & 2651.79 & 1740.49 & 2554.20 \\
\hline GFI & 0.65 & 0.80 & 0.70 & 0.79 & 0.71 & 0.78 & 0.75 & 0.81 & 0.77 & 0.78 \\
\hline $\mathrm{CFI}$ & 0.78 & 0.88 & 0.83 & 0.88 & 0.83 & 0.89 & 0.80 & 0.90 & 0.83 & 0.87 \\
\hline SRMR & 0.10 & 0.06 & 0.10 & 0.06 & 0.10 & 0.05 & 0.08 & 0.05 & 0.08 & 0.06 \\
\hline
\end{tabular}

Note: 57 out of 60 scale reliabilities are above 0.7 .

19 Durvasula, Lobo, Lysonski \& Mehta 
Table 3

Comparison of mean scores ${ }^{a}$ of service quality dimensions in life insurance and stockbrokerage

\begin{tabular}{|c|c|c|c|c|c|c|c|c|c|c|c|c|}
\hline & \multicolumn{2}{|c|}{ Perceptions } & \multicolumn{2}{|c|}{ Adequate Service } & \multicolumn{2}{|c|}{ Desired Service } & \multicolumn{2}{|l|}{$M S A^{b}$} & \multicolumn{2}{|l|}{$M S S^{C}$} & \multicolumn{2}{|l|}{$Z O T^{d}$} \\
\hline & Stkbrkr & Life ins & Stkbrkr & Life ins & Stkbrkr & Life ins & Stkbrkr & Life ins & Stkbrkr & Life ins & Stkbrkr & Life ins \\
\hline Tangibles & 3.97 & 5.13 & 4.02 & 4.40 & 5.14 & 5.63 & -0.04 & 0.72 & -1.16 & -0.48 & 1.12 & $1.22^{\mathrm{ns}}$ \\
\hline Reliability & 4.63 & 5.25 & 4.66 & 5.17 & 5.78 & 6.29 & -0.03 & $0.08^{\mathrm{ns}}$ & -1.15 & $-1.02^{\mathrm{ns}}$ & 1.12 & $1.12^{\text {ns }}$ \\
\hline Responsiveness & 4.58 & 4.97 & 4.60 & 4.86 & 5.70 & 6.03 & -0.02 & $0.10^{\text {ns }}$ & -1.12 & $-1.05^{\mathrm{ns}}$ & 1.10 & $1.17^{\text {ns }}$ \\
\hline Assurance & 5.31 & 5.04 & 5.03 & $5.08^{\text {ns }}$ & 5.99 & $6.14^{*}$ & 0.28 & -0.05 & -0.68 & -1.08 & 0.96 & $1.05^{\mathrm{ns}}$ \\
\hline Empathy & 4.44 & 4.71 & 4.36 & $4.50^{\mathrm{ns}}$ & 5.51 & $5.59^{\mathrm{ns}}$ & 0.08 & $0.21^{\mathrm{ns}}$ & -1.06 & $-0.86^{\text {ns }}$ & 1.14 & $1.09^{\text {ns }}$ \\
\hline $\begin{array}{l}\text { ServQual } \\
\text { Index }\end{array}$ & 4.59 & 4.97 & 4.53 & 4.79 & 5.62 & 5.90 & 0.05 & $0.17^{\mathrm{ns}}$ & -1.04 & $-0.92^{\mathrm{ns}}$ & 1.09 & $1.11^{\mathrm{ns}}$ \\
\hline
\end{tabular}

Note: a. Mean scores are reported on a seven-point scale $(1=$ low, $7=$ high $)$. Mean scores for stockbrokerage and life insurance samples are significantly different from each other $(p<0.05)$ unless indicated otherwise. A superscript * implies mean difference at $p<0.10$ and ns implies mean difference is not significant. b. MSA = Perception - Adequate service expectation; $c$. MSS = Perception - Desired service expectation; $d$. ZOT = Desired service expectation - Adequate service expectation

Table 4

Correlations of service quality dimensions with related measures

\begin{tabular}{|c|c|c|c|c|c|c|c|c|c|c|c|c|}
\hline \multirow[b]{2}{*}{ Correlations of: } & \multicolumn{2}{|c|}{ Tangibles } & \multicolumn{2}{|c|}{ Reliability } & \multicolumn{2}{|c|}{ Responsiveness } & \multicolumn{2}{|c|}{ Assurance } & \multicolumn{2}{|c|}{ Empathy } & \multicolumn{2}{|c|}{ ServQual Index } \\
\hline & Stkbrkr & Life ins & Stkbrkr & Life ins & Stkbrkr & Life ins & Stkbrkr & Life ins & Stkbrkr & Life ins & Stkbrkr & Life ins \\
\hline \multicolumn{13}{|c|}{ Service quality 'Perception' dimensions and } \\
\hline $\begin{array}{l}\text { Satisfaction } \\
\text { Attitudinal Loyalty } \\
\text { Behavioural } \\
\text { Loyalty }\end{array}$ & $\begin{array}{l}0.44 \\
0.40 \\
0.48\end{array}$ & $\begin{array}{l}0.52^{\mathrm{ns}} \\
0.54^{\mathrm{ns}} \\
0.51^{\mathrm{ns}}\end{array}$ & $\begin{array}{l}0.70 \\
0.64 \\
0.59\end{array}$ & $\begin{array}{l}0.74^{\mathrm{ns}} \\
0.73^{\mathrm{ns}} \\
0.69^{\mathrm{ns}}\end{array}$ & $\begin{array}{l}0.74 \\
0.72 \\
0.70\end{array}$ & $\begin{array}{l}0.71^{\mathrm{ns}} \\
0.67^{\mathrm{ns}} \\
0.67^{\mathrm{ns}}\end{array}$ & $\begin{array}{l}0.67 \\
0.69 \\
0.67\end{array}$ & $\begin{array}{l}0.80 \\
0.80 \\
0.72^{\text {ns }}\end{array}$ & $\begin{array}{l}0.71 \\
0.61 \\
0.64\end{array}$ & $\begin{array}{l}0.75^{\mathrm{ns}} \\
0.69^{\mathrm{ns}} \\
0.68^{\mathrm{ns}}\end{array}$ & $\begin{array}{l}0.77 \\
0.72 \\
0.70\end{array}$ & $\begin{array}{l}0.82^{\text {ns }} \\
0.79^{\text {ns }} \\
0.75^{\text {ns }}\end{array}$ \\
\hline \multicolumn{13}{|c|}{ Service quality 'Adequate Service' dimensions and } \\
\hline $\begin{array}{l}\text { Satisfaction } \\
\text { Attitudinal } \\
\text { Loyalty }\end{array}$ & $\begin{array}{l}0.26 \\
0.27\end{array}$ & $\begin{array}{l}0.13^{\text {ns }} \\
0.16^{\text {ns }}\end{array}$ & $\begin{array}{l}0.31 \\
0.38\end{array}$ & $\begin{array}{l}0.16^{\mathrm{ns}} \\
0.19^{\mathrm{ns}}\end{array}$ & $\begin{array}{l}0.33 \\
0.43\end{array}$ & $\begin{array}{l}0.14^{\circ} \\
0.18\end{array}$ & $\begin{array}{l}0.28 \\
0.39\end{array}$ & $\begin{array}{l}0.21^{\mathrm{ns}} \\
0.29^{\mathrm{ns}}\end{array}$ & $\begin{array}{l}0.29 \\
0.36\end{array}$ & $\begin{array}{l}0.17^{\mathrm{ns}} \\
0.25^{\mathrm{ns}}\end{array}$ & $\begin{array}{l}0.33 \\
0.42\end{array}$ & $\begin{array}{l}0.19^{\text {ns }} \\
0.26^{\text {ns }}\end{array}$ \\
\hline $\begin{array}{l}\text { Behavioural } \\
\text { Loyalty }\end{array}$ & 0.22 & $0.15^{\mathrm{ns}}$ & 0.28 & $0.18^{\text {ns }}$ & 0.36 & 0.15 & 0.30 & $0.25^{\mathrm{ns}}$ & 0.31 & $0.26^{\mathrm{ns}}$ & 0.34 & $0.25^{\mathrm{ns}}$ \\
\hline \multicolumn{13}{|c|}{ Service quality 'Desired service' dimensions and } \\
\hline $\begin{array}{l}\text { Satisfaction } \\
\text { Attitudinal } \\
\text { Loyalty }\end{array}$ & $\begin{array}{l}0.30 \\
0.31\end{array}$ & $\begin{array}{l}0.14^{\mathrm{ns}} \\
0.19^{\mathrm{ns}}\end{array}$ & $\begin{array}{l}0.39 \\
0.43\end{array}$ & $\begin{array}{l}0.18 \\
0.23\end{array}$ & $\begin{array}{l}0.41 \\
0.52\end{array}$ & $\begin{array}{l}0.16^{\mathrm{ns}} \\
0.22\end{array}$ & $\begin{array}{l}0.41 \\
0.54\end{array}$ & $\begin{array}{l}0.25^{\circ} \\
0.32\end{array}$ & $\begin{array}{l}0.36 \\
0.42\end{array}$ & $\begin{array}{l}0.22^{\mathrm{ns}} \\
0.28^{\mathrm{ns}}\end{array}$ & $\begin{array}{l}0.43 \\
0.50\end{array}$ & $\begin{array}{l}0.23^{\circ} \\
0.31\end{array}$ \\
\hline $\begin{array}{l}\text { Behavioural } \\
\text { Loyalty }\end{array}$ & 0.27 & $0.17^{\mathrm{ns}}$ & 0.43 & 0.16 & 0.48 & 0.16 & 0.46 & 0.24 & 0.38 & $0.27^{\mathrm{ns}}$ & 0.46 & 0.25 \\
\hline
\end{tabular}

Note: Life insurance sample correlations are significantly different from stock broker sample correlations unless indicated otherwise. Superscript *implies significant difference at $p<0.10$ and superscript ns implies no significant difference in correlations $(p>0.10)$. 
Table 5

Correlations of MSA and MSS dimensions with related measures

\begin{tabular}{|c|c|c|c|c|c|c|c|c|c|c|c|c|}
\hline \multirow[b]{2}{*}{ Correlations of: } & \multicolumn{2}{|c|}{ Tangibles } & \multicolumn{2}{|c|}{ Reliability } & \multicolumn{2}{|c|}{ Responsiveness } & \multicolumn{2}{|c|}{ Assurance } & \multicolumn{2}{|l|}{ Empathy } & \multicolumn{2}{|c|}{ ServQual Index } \\
\hline & Stkbrkr & Life ins & Stkbrkr & Life ins & Stkbrkr & Life ins & Stkbrkr & Life ins & Stkbrkr & Life ins & Stkbrkr & Life ins \\
\hline \multicolumn{13}{|c|}{ Service quality 'MSA' dimensions and } \\
\hline $\begin{array}{l}\text { Satisfaction } \\
\text { Attitudinal Loyalty } \\
\text { Behavioural } \\
\text { Loyalty }\end{array}$ & $\begin{array}{l}0.21 \\
0.16 \\
0.18\end{array}$ & $\begin{array}{l}0.32^{\text {ns }} \\
0.31 \\
0.16^{\text {ns }}\end{array}$ & $\begin{array}{l}0.36 \\
0.25 \\
0.29\end{array}$ & $\begin{array}{l}0.52^{*} \\
0.48 \\
0.25^{\text {ns }}\end{array}$ & $\begin{array}{l}0.41 \\
0.30 \\
0.34\end{array}$ & $\begin{array}{l}0.48^{\text {ns }} \\
0.41^{\text {ns }} \\
0.30^{\text {ns }}\end{array}$ & $\begin{array}{l}0.32 \\
0.22 \\
0.29\end{array}$ & $\begin{array}{l}0.57 \\
0.50 \\
0.22^{\text {ns }}\end{array}$ & $\begin{array}{l}0.43 \\
0.27 \\
0.33\end{array}$ & $\begin{array}{l}0.57^{*} \\
0.46 \\
0.27^{\text {ns }}\end{array}$ & $\begin{array}{l}0.42 \\
0.29 \\
0.35\end{array}$ & $\begin{array}{l}0.61 \\
0.53 \\
0.29^{\text {ns }}\end{array}$ \\
\hline \multicolumn{13}{|c|}{ Service Quality 'MSS' Dimensions and } \\
\hline $\begin{array}{l}\text { Satisfaction } \\
\text { Attitudinal } \\
\text { Loyalty }\end{array}$ & $\begin{array}{l}0.15 \\
0.11\end{array}$ & $\begin{array}{l}0.36 \\
0.33\end{array}$ & $\begin{array}{l}0.36 \\
0.27\end{array}$ & $\begin{array}{l}0.55 \\
0.50\end{array}$ & $\begin{array}{l}0.46 \\
0.36\end{array}$ & $\begin{array}{l}0.52^{\text {ns }} \\
0.43^{\text {ns }}\end{array}$ & $\begin{array}{l}0.38 \\
0.28\end{array}$ & $\begin{array}{l}0.61 \\
0.55\end{array}$ & $\begin{array}{l}0.41 \\
0.26\end{array}$ & $\begin{array}{l}0.57^{\circ} \\
0.47\end{array}$ & $\begin{array}{l}0.42 \\
0.30\end{array}$ & $\begin{array}{l}0.64 \\
0.55\end{array}$ \\
\hline $\begin{array}{l}\text { Behavioural } \\
\text { Loyalty }\end{array}$ & 0.12 & 0.33 & 0.23 & 0.51 & 0.37 & $0.49^{\text {ns }}$ & 0.33 & 0.53 & 0.32 & $0.47^{\mathrm{ns}}$ & 0.33 & 0.56 \\
\hline
\end{tabular}

Note: Life insurance sample correlations are significantly different from stock broker sample correlations unless indicated otherwise. Superscript * implies significant difference at $p<0.10$ and superscript ns implies no significant difference in correlations $(p>0.10)$.

Figure 1

Hi-Lo plot showing mean scores of adequate, actual and desired service perceptions

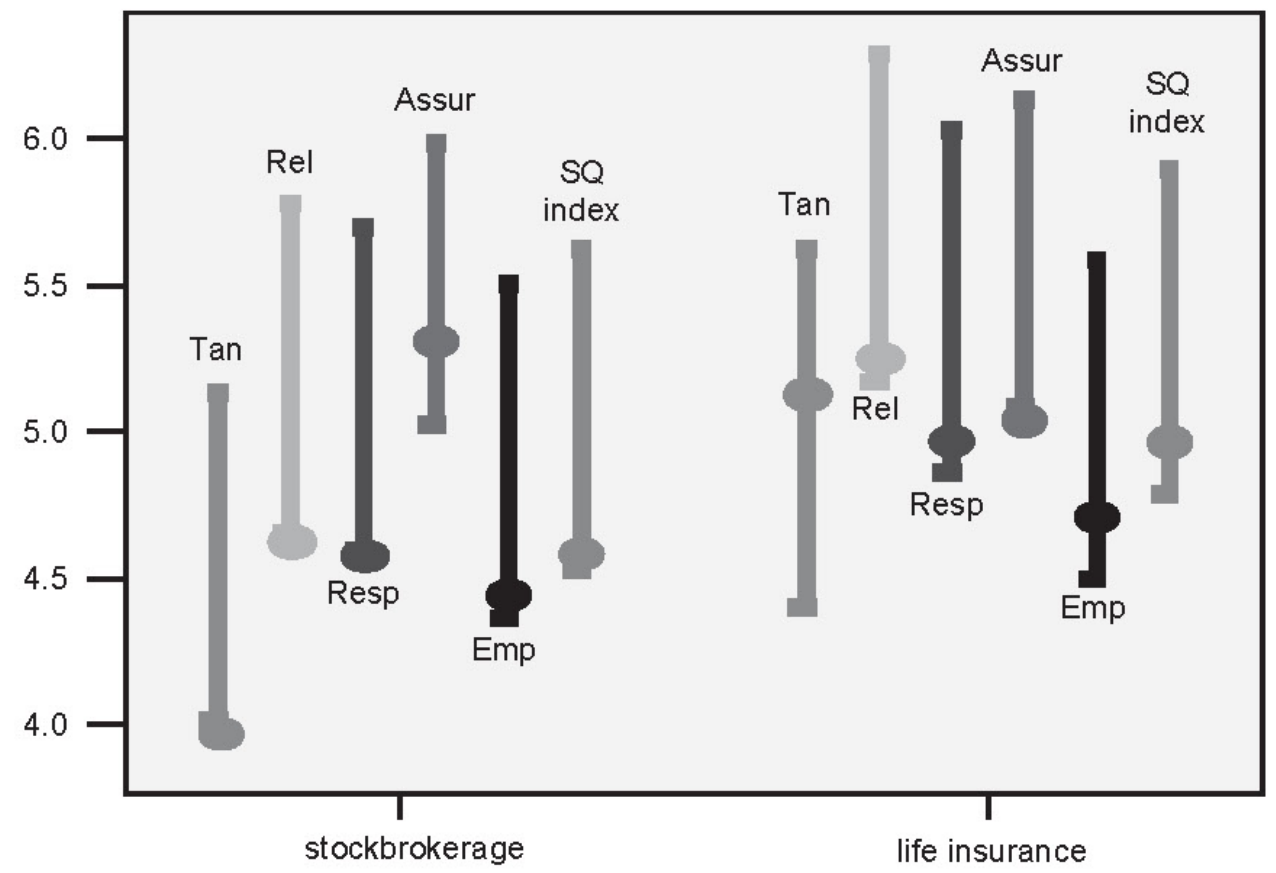

Note: Figure shows adequate service level (lower end of the line), desired service level (upper end of the line), and mean perceptions of actual service (solid circle).

21 Durvasula, Lobo, Lysonski \& Mehta 